\title{
Site Selection \& Characterization Status Report for Next Generation Nuclear Plant (NGNP)
}

Mark Holbrook Scott Beck Ken Moor Gerald Sehlke

September 2007

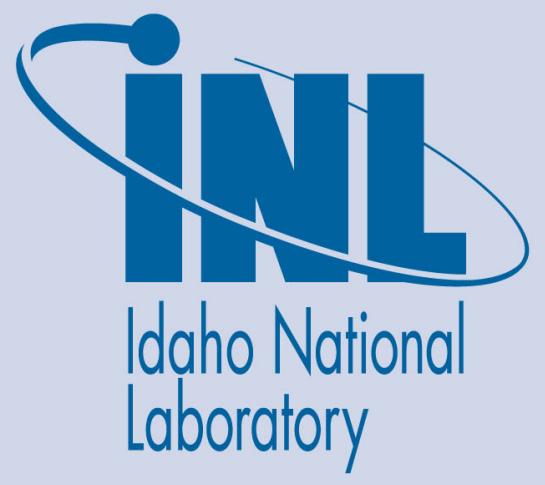

The INL is a U.S. Department of Energy National Laboratory operated by Battelle Energy Alliance 
INL/EXT-12-25796

\title{
Site Selection \& Characterization Status Report for Next Generation Nuclear Plant (NGNP)
}

\author{
Mark Holbrook \\ Scott Beck \\ Ken Moor \\ Gerald Sehlke
}

September 2007

\author{
Idaho National Laboratory \\ Next Generation Nuclear Plant (NGNP) Project \\ Idaho Falls, Idaho 83415
}

http://www.inl.gov

Prepared for the

U.S. Department of Energy

Office of Nuclear Energy

Under DOE Idaho Operations Office

Contract DE-AC07-05ID14517 


\section{CONTENTS}

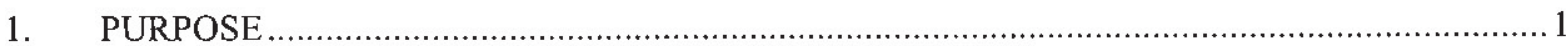

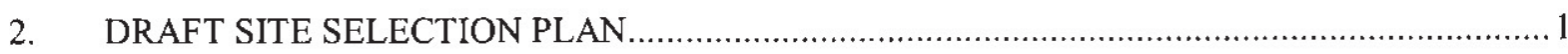

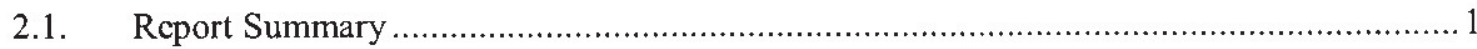

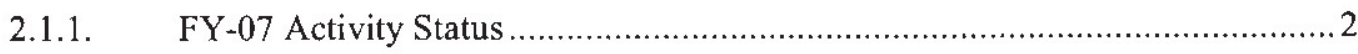

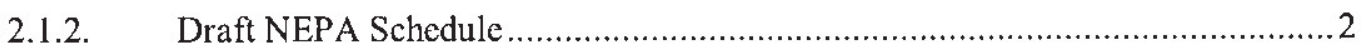

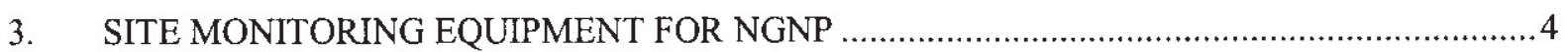

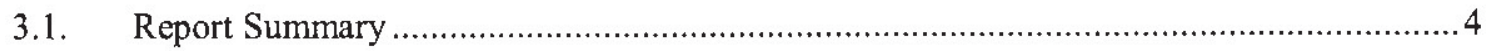

3.1.1. Environmental Surveillance Programs .................................................... 4

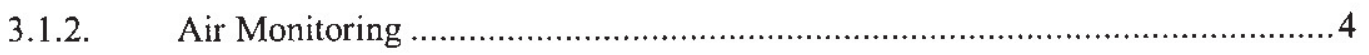

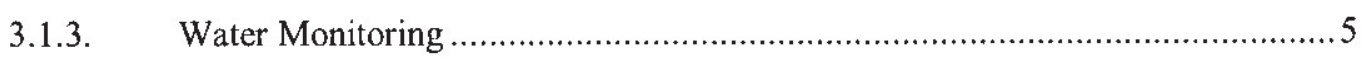

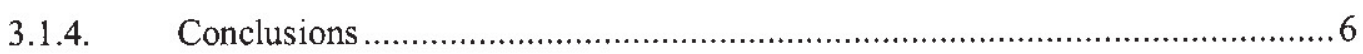

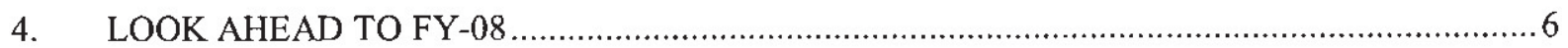

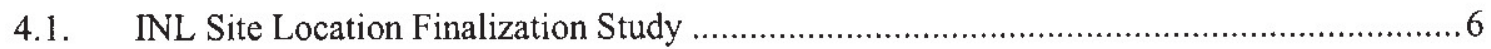

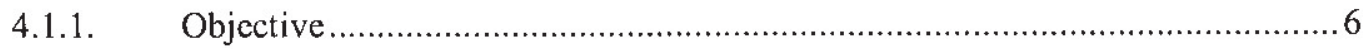

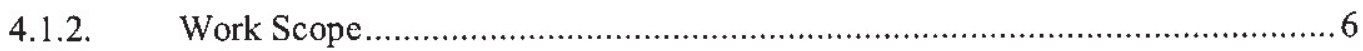

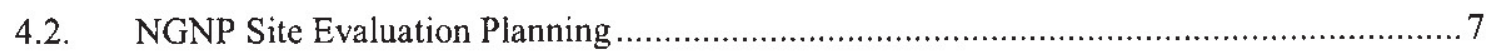

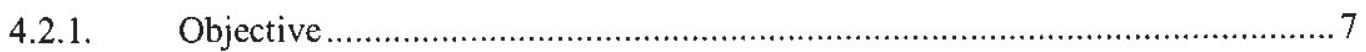

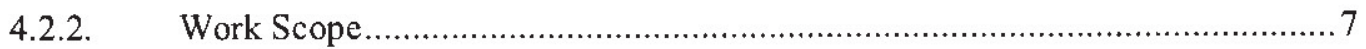

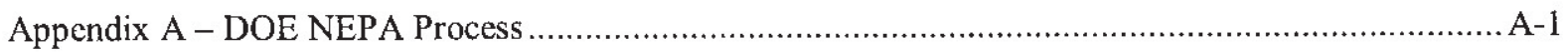

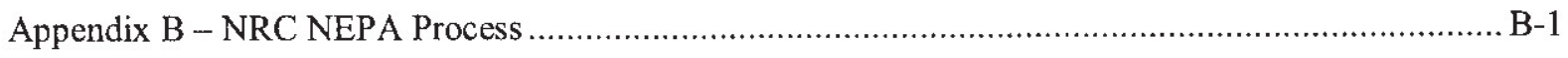

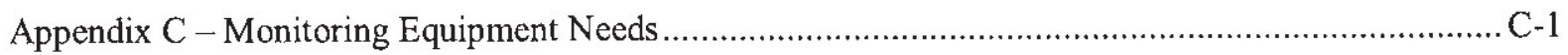




\section{PURPOSE}

In the near future, the U.S. Depart of Energy (DOE) will need to make important decisions regarding design and construction of the Next Generation Nuclear Plant (NGNP). One part of making these decisions is considering the potential environmental impacts that this facility may have, if constructed here at the Idaho National Laboratory (INL). The National Environmental Policy Act (NEPA) of 1969 provides DOE decision makers with a process to systematically consider potential environmental consequences of agency decisions. In addition, the Energy Policy Act of 2005 (Title VI, Subtitle C, Section 644) states that the "Nuclear Regulatory Commission (NRC) shall have licensing and regulatory authority for any reactor authorized under this subtitle." This stipulates that the NRC will license the NGNP for operation. The NRC NEPA Regulations (10 CFR Part 51) require that the NRC prepare an Environmental Impact Statement (EIS) for a permit to construct a nuclear power plant. The applicant is required to submit an Environmental Report (ER) to aid the NRC in complying with NEPA.

This report provides a status of the NGNP-related activities that were taken in FY-07 to prepare for selecting a site for the NGNP and the advanced planning performed to address the future DOE/NRC (NEPA) process for assessing the potential environmental impacts from such a facility. In addition, activities planned for FY- 08 will be provided.

\section{DRAFT SITE SELECTION PLAN}

On January 12, 2007, INL provided the draft "NGNP Site Selection \& Characterization Plan" to DOE. The purpose of this report was to provide an overview of the proposed steps for selecting a site for the NGNP and the NEPA process for assessing the potential environmental impacts from such a facility. Discussion included the basis for the initial Site E selection, an overview of the DOE EIS process, a description of how the NEPA review fits within the NRC licensing process, and a proposed high-level schedule for site characterization-related activities. Highlights from that report are provided below.

\subsection{Report Summary}

In 1983, a site selection was performed by the DOE for the New Production Reactor (NPR) at the INL. In 1989, the original site selection process was reviewed to determine if the primary site selected in 1983 was still considered the best site in light of the most recent site characterization data (see Report EGG-NPR-8517, Rev. 1, "Site Selection Report for the New Production Reactor at the Idaho National Engineering Laboratory," dated July 1989). This report determined that there was no reason to alter the previously selected primary location (called "Site E") for the NPR.

One advantage to Site $E$ is that it is close to established roads, the railroad, and the INL site electrical transmission loop. Considerable resources were expended in characterizing the selected site that is located east of the Reactor Test Complex (RTC). Given the type of facility that is planned, it is logical that Site E would be a prime candidate for the initial siting studies associated with locating the NGNP facility. 


\subsubsection{FY-07 Activity Status}

The INL initiated a group of preconceptual design activities to focus and prioritize research and development work and to prepare for the conceptual design phase of the NGNP. This work included site layout activities that used the original NPR Site $\mathrm{E}$ as the preferred site for the purpose of these studies. However, the Site E selection should be reassessed in light of current siting requirements as we move into the next phase of project development. Selecting an expected location for the NGNP facility is one of the first activities that should take place during conceptual design. Once this is complete, DOE will make an announcement to the public and initiate development of an EIS. This process is discussed in Appendix A of this report.

NRC liccnsing activities will also include a NEPA review. Therefore, much of the information gathered to support development of a DOE EIS can be used by the Environmental Report that is submitted as part of an NRC Early Site Permit or a Construction Permit application. A description of the Environmental Report development process and a summary of the Environmental Report contents are provided in Appendix B of this report.

To support the site selection analysis, it would be cost beneficial to gather existing site characterization data from the NPR Site E evaluations that were originally developed in the late 1980 s. However, much of that data is currently controlled by the Idaho Cleanup Project (ICP). Therefore, activities were initiated in FY -07 to collect the existing NPR site characterization data. These data are being collected and stored in the ROB building.

\subsubsection{Draft NEPA Schedule}

Figure 1 lays out a proposed schedule for development of the site evaluation, DOE EIS, and the eventual Environmental Report that is necessary for NRC licensing. This activity assumes that the NPR Site E will bccome the preferred location for the NGNP. However, as noted above, separate engineering studies will occur to evaluate the suitability of Site $\mathrm{E}$ for our purposes. In any case, understanding the usefulness of existing NPR Site E data will be critical to the site sclection decision-making process. 


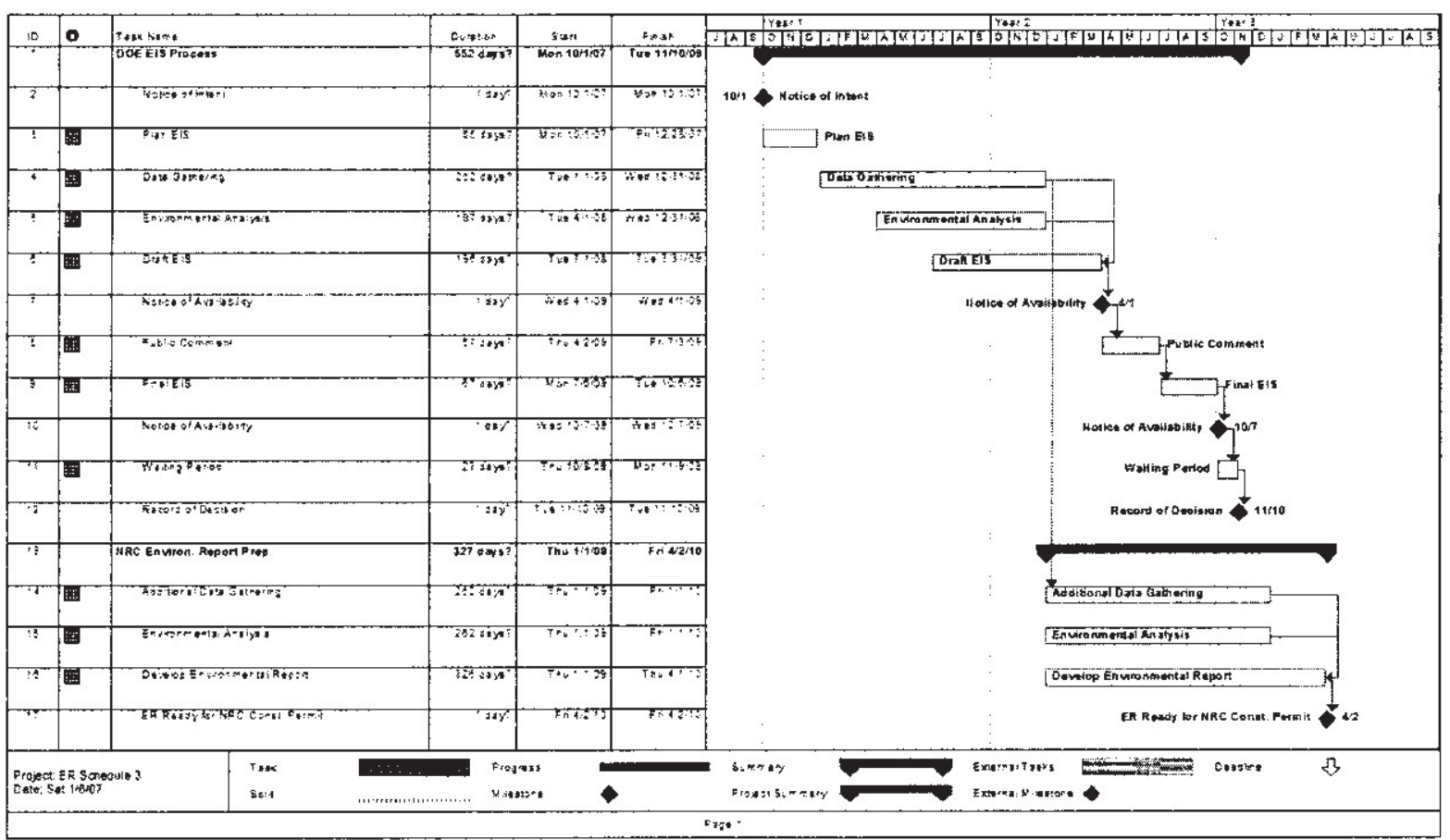

Figure 1 - Integrated NEPA Development Schedule

Notes:

- A decision on the part of DOE to issue a Notice of Intent for construction of the NGNP provides the starting point for the schedule provided above.

- The task breakdown and durations will be reevaluated during conceptual design phase as part of the Environmental Compliance Report.

- These work activities will be refined as the public/private partnership is developed and as the NRC licensing strategy is finalized.

- The NRC ER data analysis builds upon the data and analysis work performed during development of the DOE EIS. NRC licensing requires a total of 24 months of site metcorological data gathering. 


\section{SITE MONITORING EQUIPMENT FOR NGNP}

On March 30, 2007, INL provided the "Site Monitoring Equipment for NGNP" report to DOE. The purpose of this report was to document the NGNP site monitoring needs at the INL. This report focused primarily on air and water monitoring requirements and needs.

\subsection{Report Summary}

\subsubsection{Environmental Surveillance Programs}

DOE Order 5400.1 states that an environmental surveillance program shall be conducted to monitor the effects, if any, of DOE activities on on-site and offsite environmental and natural resources. It also states that environmental surveillance programs shall be designed to satisfy one or more of the following program objectives:

- Verify compliance with applicable environmental laws and regulations;

- Verify compliance with environmental commitments made in Environmental Impact Statements, Environmental Assessments, Safety Analysis Reports, or other official DOE documents;

- Characterize and define trends in the physical, chemical and biological condition of environmental media;

- Establish baselines of environmental quality;

- Provide a continuing assessment of pollution abatement programs;

- Identify and quantify new or existing environmental quality problems.

\subsubsection{Air Monitoring}

Air Monitoring (Emissions) - DOE Order 5400.1 states that air emission monitoring shall be in accordance with the requirements of applicable Federal, State, and local regulations authorized by the Clean Air Act (42 U.S.C. 7401 , et. seq.). It also states that large permanent facilities or modification to such facilities may require a Prevention of Significant Deterioration (PSD) permit prior to construction. In addition to pre- and post-operational emission testing, the permit process may require up to a year of meteorological and ambient air quality monitoring. Siting of monitoring stations requires the use of atmospheric dispersion modeling to locate areas of expected maximum offsite impact. DOE Order 5400.1 states that ambient air quality monitoring programs should be designed to accomplish the following:

- Establish background concentration levels of pertinent chemical species;

- Determine the highest concentrations of the pertinent pollutant species expected to occur in the vicinity of DOE operations;

- Determine representative pollutant concentrations at areas where public health and other concerns should be considered; and

- Evaluate the effects of emissions on ambient levels of pertinent contaminants. 


\subsubsection{Water Monitoring}

DOE ORDER 5400.1 states that ambient water quality monitoring should be conducted through a network of fixed stations from which data will establish well-defined histories of the physical, biological, and chemical conditions of local bodies of water and sediments. The data obtained from this network should be coordinated with other monitoring activities. Water quality data may be obtained from existing State and local monitoring stations. It further states that analysis of data collected from a fixed station monitoring network should support:

- Characterizing and defining trends in the physical, chemical, and biological condition of surface waters;

- Establishing baselines of water quality;

- A continuing assessment of water pollution control programs;

- Identifying new water quality problems; and

- Detecting, characterizing, and reporting unplanned releases and their effects on water quality.

DOE Order 5400.1 states that monitoring networks should be operated and maintained in a uniform manner (i.e., through established procedures that allow comparative evaluations of data from monitoring sites) based on receiving water characteristics which may be determine by reconnaissance surveys or mathematical modeling.

DOE Order 5400.1 states that ground water that is or could be affected by DOE activities shall be monitored to determine and document the effects of operations on groundwater quality and quantity and to demonstrate compliance with DOE requirements and applicable Federal, State, and local laws and regulations. Further, it states that groundwater monitoring programs shall be conducted on-site and in the vicinity of DOE facilities to:

- Obtain data for the purpose of determining baseline conditions of groundwater quality and quantity;

- Demonstrate compliance with and implementation of all applicable regulations and DOE Orders;

- Provide data to permit the early detection of groundwater pollution or contamination;

- Provide a reporting mechanism for detected groundwater pollution or contamination;

- Identify existing and potential groundwater contamination sources and to maintain surveillance of these sources;

- Provide data upon which decisions can be made concerning land disposal practices and the management and protection of groundwater resources.

DOE Order 5400.1 states that site-specific characteristics shall determine monitoring needs. Where appropriate, groundwater monitoring programs shall be designed and implemented in accordance with 40 CFR Part 264, Subpart F, or 40 CFR Part 265, Subpart F. For sites with multiple groundwater pollutant sources, extensive groundwater pollution or other unique site 
problems, groundwater monitoring programs could require more extensive information than those specified in 40 CFR Parts 264 and 265. Monitoring for radionuclides shall be in accord with DOE Orders in the 5400 series dealing with radiation protection of the public and the environment.

\subsubsection{Conclusions}

Appendix $\mathrm{C}$ includes a summary of the required monitoring equipment anticipated to fulfill the necessary requirements of the NGNP site monitoring and characterization needs (DOE Order 5400.1 Chapter IV, Environmental monitoring requirements, Section 3, "Preoperational Monitoring of Facilities Sites, and Operations"). Total cost for this equipment is projected to be approximately $\$ 140,000$ in FY-07 money.

\section{PROJECTED FY-08 ACTIVITIES}

The work scope for FY-08 will address the reevaluation of the NPR Site E suitability and planning for the EIS and Environmental Report development tasks. These tasks are described below.

\subsection{INL Site Location Finalization Study}

\subsubsection{Objective}

The objective of this Engineering Department task is to confirm the benefits of using the NPR Site $\mathrm{E}$ versus other available site locations at the INL. This will include consideration of existing geotechnical and seismic data and analysis, water table, location relative to roadways, railroad access and electrical transmission lines, topography, and other relevant factors.

\subsubsection{Work Scope}

The work scope for the study includes the following:

- Review the NPR Site Selection Report as a basis for the NGNP report format and content. Specifically review the NPR site sclection criteria and modify it for the NGNP and its characteristics as they differ from the NPR at the INL.

- Develop INL site alternatives based on the characteristics of the NGNP and the current and planned facilities at the INL. Included will be site characteristics such as: seismic, geology, access, INL flood plain, depth to rock, range fires, archeological and historical sites, etc.

- Prioritize all NGNP alternative sites with a documented basis that is based on the site selection criteria.

- Conduct meetings with stakeholders to evaluate study results.

This study is estimated to be complete by June 2008 . 


\subsection{NGNP Site Evaluation Planning}

\subsubsection{Objective}

The objective of this Licensing task is to develop a strategy for complying with the environmental requirements of NRC and DOE including NEPA for siting and licensing NGNP facilities at the INL and documenting that process in an Environmental Compliance Plan.

\subsubsection{Work Scope}

The work scope for this task includes the following:

- Conduct meetings with INL staff, consultations with engineering group, NEPA consultations, and with DOE and NRC.

- Identify detailed Environmental Report and EIS environmental requirements.

- Identify any legislative, regulatory, or other legal constraints and mitigative actions.

- Identify, validate, and verify existing documentation and its suitability to support the Environmental Report and NEPA requirements.

- Identify need for additional information to support Environmental Report and NEPA requirements, including: 1) footprint, 2) seismic, 3) stormwater/floodplain, and et. al, including cultural resources, flora and fauna, meteorology, population distribution, economics.

- Prepare Draft Summary Documentation Report that will consist of a report that details the nature and validity of existing technical information and identifies gaps between the existing information and the information that would be required to support the preparation of an Environmental Report and EIS and support the permitting and licensing efforts needed to site the NGNP facilities at INL.

- Prepare Draft Environmental Compliance Plan.

The draft Environmental Compliance Plan is scheduled for completion by April 30, 2008. 


\section{Appendix A}

\section{DOE NEPA Process}

Prior to constructing a nuclear facility, the DOE must assess the potential impacts that the facility may have on the environment. This is to ensure that the following NEPA goals are met:

1. Fulfill the responsibilitics of cach generation as trustee of the environment for succeeding generations;

2. Assure for all Americans safe, healthful, productive, and aesthetically and culturally pleasing surroundings;

3. Attain the widest range of beneficial uses of the environment without degradation, risk to health or safety, or other undesirable and unintended consequences;

4. Preserve important historic, cultural, and natural aspects of national heritage, and maintain, wherever possible, an environment which supports diversity and variety of individual choice;

5. Achieve a balance between population and resource use which will permit high standards of living and wide sharing of life's amenities; and

6. Enhance the quality of renewable resources and approach the maximum attainable recycling of depletable resources.

Figure A-1 lays out the overall NEPA process that starts with a decision on the part of DOE to prepare an EIS.

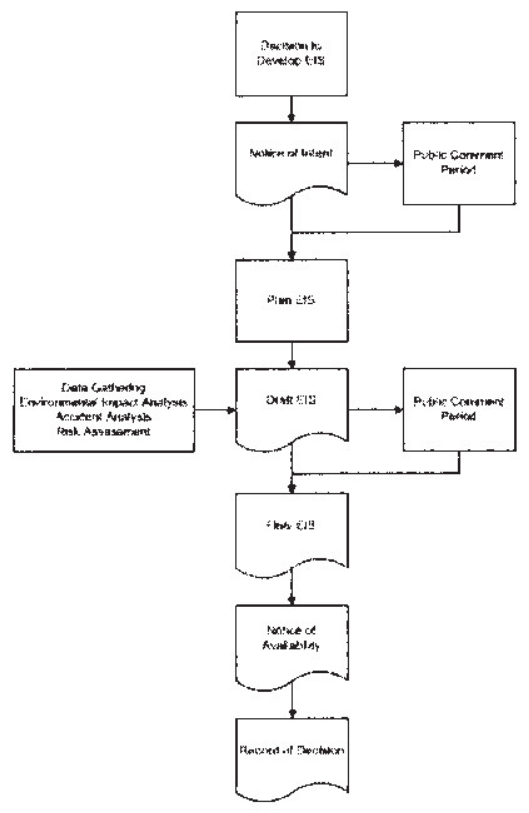

Figure A-1 DOE NEPA Process 
At the end of this process (if no significant environmental impacts are found), DOE issues a Finding of No Significant Impact (FONSI) and announces that it will move forward with the NGNP project.

In addition, the NGNP preliminary design process continues and moves toward development of the products needed for NRC licensing of the NGNP. This includes development of an Environmental Report (ER) that uses much of the same information included in the DOE EIS, but is then reviewed by the NRC. The next section describes the NRC review process. 


\section{Appendix B}

\section{NRC NEPA Process}

The NRC maintains oversight of the construction and operation of a facility throughout its lifetime to assure compliance with the Commission's regulations for the protection of public health and safety, the common defense and security, and the environment. To implement this process, all nuclear power plant applications must undergo a safety review, an environmental review, and antitrust review by the NRC.

In accordance with 10 CFR Part 50, an application for a NRC Construction Permit (CP) must contain four types of information:

1. Preliminary safety analyses,

2. An environmental review,

3. Financial and antitrust statements, and

4. Assessment of the need for the power plant.

The CP application includes a Preliminary Safety Analysis Report (PSAR). This document contains the design information and criteria for the proposed reactor and comprehensive data on the proposed site. It also discusses various hypothetical accident situations and the safety features of the plant that prevents accidents or, if accidents should occur, lessens their effects. In addition, the application must contain a comprehensive assessment of the environmental impacts and information for antitrust reviews of the proposed plant.

\section{Site Technical Review}

The NRC staff reviews the CP application to determine whether the plant design meets all applicable regulations (10 CFR Parts 20, 50,73, and 100). The review includes, in part:

- Characteristics of the site, including surrounding population, seismology, meteorology, geology and hydrology,

- Design of the nuclear plant,

- Anticipated response of the plant to hypothetical accidents,

- Plant operations including the applicant's technical qualifications to operate the plant,

- Discharges from the plant into the environment (i.e., radiological effluents), and

- Emergency plans.

When the NRC completes its review, it prepares a Safety Evaluation Report (SER) summarizing the anticipated effect of the proposed facility on public health and safety. 


\section{NEPA Review}

The NRC NEPA Regulations, at 10 CFR Part 51, require that the NRC prepare an Environmental Impact Statement (EIS) for a permit to construct a nuclear power reactor. The permit applicant is required to submit an ER to aid the NRC in complying with NEPA, and the NRC is responsible for evaluating the reliability of any of the information that it uses to prepare the EIS. After completing this review, the NRC issues a Draft Environmental Impact Statement (EIS) for comment by the appropriate Federal, State, and local agencies as well as by the public.

Afterwards, the agency issues a Final EIS that addresses all comments received.

\section{NRC Environmental Review Process}

Figure B-1 lays out the overall process for ER development, submittal as part of the construction permit, and the NRC staff's subsequent development of the EIS.

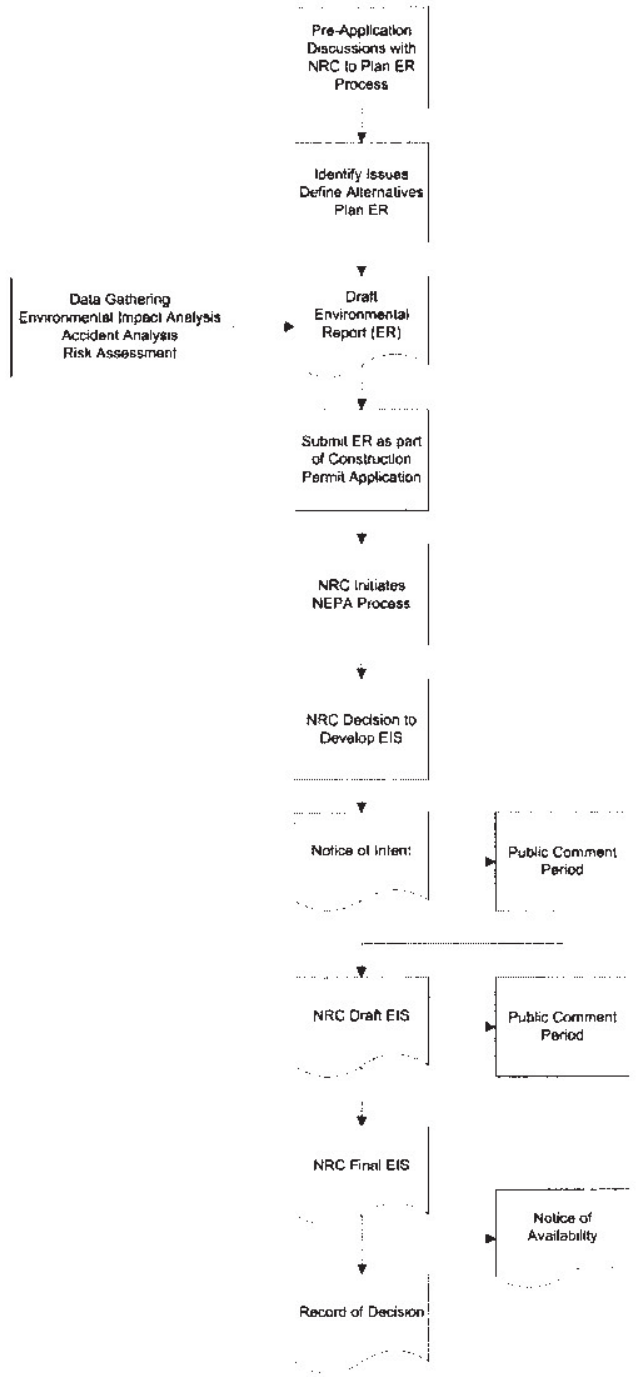

Figure B-1 Environmental Report Review Process 
Key points associated with Figure B-1 include the following:

- The NGNP project is responsible for identifying issues, defining alternatives, planning the ER development, gathering the necessary data, and performing the various analyses and risk assessments. It is expected that some of this work will be performed by subcontractors.

- Once the ER is completed and submitted to the NRC as part of the construction permit, the NRC takes over and uses the ER as a reference for their EIS development and assessment. This EIS is then made available to the public and comments are incorporated into the final EIS and a record of decision is issued.

- As noted earlier, some issues may not be fully addressed at the Construction Permit Stage. These issues are carried over and are resolved during the Operating License Stage after the necessary information is available and evaluated.

\section{Environmental Report Contents}

The contents for an ER are specified in 10 CFR 51.30. The ER contains a description of the proposed action, a statement of its purposes, and a description of the environment affected, and discusses the following considerations:

- The impact of the proposed action on the environment, discussed in proportion to their significance.

- Any adverse environmental effects that cannot be avoided should the proposal be implemented.

- Alternatives to the proposed action. The discussion of alternatives must be sufficiently complete to aid the NRC in developing and exploring, pursuant to section 102(2)(E) of NEPA, "appropriate alternatives to recommended courses of action in any proposal which involves unresolved conflicts concerning alternative uses of available resources." To the extent possible, the environmental impacts of the proposal and the alternatives should be presented in comparative form.

- The relationship between local short-term uses of man's environment and the maintenance and enhancement of long-term productivity.

- Any irreversible and irretrievable commitments of resources that would be involved in the proposed action should it be implemented.

The following subsections cover the ER organization and content, including a description of the various types of environmental data that must be gathered in advance to support development of the ER. The basis for this information is found in NRC Regulatory Guide 4.2, Rev 2, "Preparation of Environmental Reports for Nuclear Power Stations," dated July 1976.

\section{Chapter 1 - Purpose of Proposed Facility}

This first chapter of the ER documents the purpose and the benefits of the NGNP with respect to the power requirements to be satisfied, the system reliability to be achieved, and any other primary objectives for the facility. Given the uniqueness of the NGNP and its associated 
hydrogen/process heat generation capabilities, this first chapter will contain descriptive information that differs significantly from a typical commercial power plant proposal.

\section{Chapter 2 - Site and Environmental Interfaces}

This chapter contains the applicable information related to the physical, biological, and human characteristics of the site's environment that could be affected by the construction and operation of the NGNP facility. This includes a discussion of the geography and demography of the site and surrounding area. Other types of data presented in this chapter include the following:

- Ecology - Describe the flora and fauna in the vicinity of the site, their habitats, and their distribution. Establish the identity of the majority of terrestrial and aquatic organisms on or near the site and their relative abundances. Identify any definable preexisting environmental stresses from sources such as pollutants. Information should be presented in two separate subsections ("Terrestrial Ecology" and "Aquatic Ecology").

- Meteorology - Provide a meteorological description of the NGNP site and its surrounding area. Include the use of at least one annual cycle from the onsite meteorological program for a construction permit application and at least two annual cycles, including the most recent 1-year period for an operating license application.

- Hydrology - Describe, in qualitative terms, the physical, chemical, biological, and hydrological characteristics, the typical seasonal ranges and averages, and the historical extremes for surface and ground water bodies. Information is needed only for those waters that may affect station effluents and water supply or that may be assumed to be affected by the construction or operation of the NGNP facility. For those water bodies and systems that may receive radionuclides from the NGNP facility, the data should be supplied out to a 50 mile radius from the facility.

- Geology - Describe the major geological aspects of the site and its immediate environs. Except for those specific features that are relevant to the environmental impact assessment, the discussion may be limited to noting the broad features and general characteristics of the site and environs (i.e., topography, stratigraphy, and soil and rock types).

- Historic, Archeological, Architectural, Scenic, Cultural, and Natural Features - The ER should include a brief discussion of the significance of any of these issues relative to the NGNP site, with specific attention to the sites and areas listed in the Natural Registry of Natural Landmarks and properties included in or eligible for inclusion in the National Register of Historic Places.

- Noise - Ambient noise levels obtained from the surrounding biotic communities within five miles of the NGNP site location should be reported. Particular attention should be directed toward obtaining acoustic noise levels where high voltage transmission lines are located.

\section{Chapter 3 - The Station}

The NGNP facility and the transmission system are described in this chapter. Since environmental effects are of particular interest in the ER, NGNP effluents and other facility systems that interact with the environment should be described in detail. Depending on the 
timing of the completion of the NGNP design, this chapter could present a real challenge.

Detailed system knowledge will be required to estimate and identify the radioactive source terms and chemical effluents that will result from the NGNP facility. Therefore, development of a NGNP-applicable plant parameter envelop (PPE) may be necessary if adequate design information is not available during preparation of the construction permit ER. Some issues may also be resolved in the Final ER provided during the Operating License Stage.

\section{Chapter 4 - Environmental Effects of Site Preparation and Construction}

This chapter should discuss the expected effects of site preparation, and NGNP and transmission facility construction. The effects are to be presented in terms of the impact on the resources and populations described in Chapter 2. Methods used to determine these impacts should be described.

\section{Chapter 5 - Environmental Effects of Station Operation}

This chapter is intended to describe the interaction of the NGNP facility (discussed in Chapter 3) and the environment (discussed in Chapter 2). Planned actions to reduce undesirable effects caused by NGNP operation should be described in detail. Effects that are temporary or subject to later amelioration should be distinguished from other effects that are unavoidable and irreversible.

\section{Chapter 6 - Effluent and Environmental Measurements and Monitoring Programs}

The means by which baseline data presented in the other chapters should be described in this chapter. This description should include plans and programs for monitoring the environmental impacts of NGNP site preparation, facility construction, and NGNP operation.

\section{Chapter 7 - Environmental Effects of Accidents}

This chapter should discuss the potential environmental effects of accidents involving the NGNP facility. This discussion should include accidents involving radioactivity, chemical explosions, fires, and oil or toxic material spills.

\section{Chapter 8 - Economic and Social Effects of Construction and Operation}

This chapter should describe our assessment of the economic and social effects of the NGNP facility. Given the difficult task of accurately assessing the economic benefits and costs related to operation of a facility over a long period of time, this assessment should focus on those benefits and costs that are measurable, such as the generated electricity and the capital, operating, and maintenance costs.

\section{Chapter 9 - Alternative Energy Sources and Sites}

The basis for the NGNP site selection should be documented in this chapter. Normally, this chapter would discuss the range of alternatives and the rationale that led to selection of the site and the choice of nuclear power as the selected energy source. However, the directed research and development mission of the NGNP project may require us to be creative as we develop this chapter.

\section{Chapter 10 - Station Design Alternatives}


This chapter should describe how the NGNP project arrived at the facility design through consideration of alternative designs for systems.

\section{Chapter 11 - Summary Cost-Benefit Analysis}

The NGNP project should develop an analysis that demonstrates that the total benefits outweigh the total costs.

\section{Chapter 12 - Environmental Approvals and Consultation}

This chapter should list all Federal permits, licenses, approvals, and other entitlements that must be obtained and describe the status of compliance with these requirements. The ER should also include a discussion of the status of compliance with applicable environmental quality standards and requirements including, but not limited to, applicable zoning and land-use regulations, and thermal and other water pollution limitations or requirements that have been imposed by federal, state, regional, and local agencies having responsibility for environmental protection.

\section{Chapter 13 - References}

This chapter provides a bibliography of the sources used in preparation of the ER. 


\section{Appendix C}

\section{Monitoring Equipment Needs}

The environmental monitoring program is designed to comply with all the applicable regulatory requirements of the NRC, DOE guidance and NGNP directives. The work scope required to ensure compliance depends on several factors including:

- The NGNP program phasc: pre-construction, construction, pre-operations, operations, or D\&D.

- Anticipated releases and potential impacts of radioactive or chemical pollutants.

- Existing natural and manmade environmental conditions that may affect program design such as existing ground water contamination in the Snake River aquifer, emissions of the stable or radioactive materials from existing facilities, or the need to characterize an area within a naturally variable environment before disturbing that area.

The basis for the design of each environmental monitoring program is driven by 1) Federal and State regulations, requirements, agreements, and directives that are to be enforced, 2) the general environment where the monitoring program will be instituted, 3 ) the type of pathways that are available to transport radioactive and chemical emissions to the environment and 4) the type and quantity of emissions likely to be encountered during monitoring. These four activities will determine the work scope to implement the environmental monitoring program.

Table C-1 is summary of the required monitoring equipments anticipated to fulfill the necessary requirements of the NGNP site monitoring and characterization needs (DOE Order 5400.1 Chapter IV, Environmental monitoring requirements, Section 3, "Preoperational Monitoring of Facilities Sites, and Operations").

Table C-1 - List of Required Air Monitoring Equipment

\begin{tabular}{|c|c|c|c|c|}
\hline EQUIPMENT & DESCRIPTION & $\begin{array}{c}\text { UNITS } \\
\text { REQUIRED }\end{array}$ & $\begin{array}{l}\text { UNIT } \\
\text { COST }\end{array}$ & $\begin{array}{l}\text { TOTAL } \\
\text { COST }\end{array}$ \\
\hline $\begin{array}{l}\text { Portable Wind } \\
\text { Measurement } \\
\text { Station }\end{array}$ & $\begin{array}{l}\text { Data logging of wind speed and } \\
\text { direction. Self supporting, } 110 \text { volt AC } \\
\text { power. Housed in heated hut. }\end{array}$ & 4 & $\$ 3,000$ & $\$ 6,000$ \\
\hline $\begin{array}{l}\text { High Volume Air } \\
\text { Samples }\end{array}$ & $\begin{array}{l}10 \text { micron high volume size selective } \\
\text { inlet with critical Venturi Meter constant } \\
\text { flow controllers and flow totalizer with } \\
\text { capability for measuring both total } \\
\text { suspended particulate (TSP) and } \\
\text { compliance with EPA PM-10 standards }\end{array}$ & 2 & $\$ 6,800$ & $\$ 13,600$ \\
\hline $\begin{array}{l}\text { Low Volume } \\
\text { Samplers (for gross } \\
\text { alpha, beta) }\end{array}$ & $\begin{array}{l}\text { Continuous duty with constant flow air } \\
\text { sampling system. Digital timer, AC } \\
\text { powered, and filter holder }\end{array}$ & 2 & $\$ 2,500$ & $\$ 5,000$ \\
\hline $\begin{array}{l}\mathrm{NO} / \mathrm{NO}_{2} / \mathrm{NO}_{x} \\
\text { Ambient Air } \\
\text { Analyzer }\end{array}$ & $\begin{array}{l}\text { Low-level chemi-luminescent } \\
\mathrm{NO} / \mathrm{NO}_{2} / \mathrm{NO}_{X} \text { Ambient Air Analyzer with } \\
\text { a detection limit of } 50 \mathrm{ppt} \text {, }\end{array}$ & 2 & $\$ 15,700$ & $\$ 31,400$ \\
\hline
\end{tabular}




\begin{tabular}{|c|c|c|c|c|}
\hline EQUIPMENT & DESCRIPTION & $\begin{array}{l}\text { UNITS } \\
\text { REQUIRED }\end{array}$ & $\begin{array}{l}\text { UNIT } \\
\text { COST }\end{array}$ & $\begin{array}{l}\text { TOTAL } \\
\text { COST }\end{array}$ \\
\hline & $\begin{array}{l}\text { microprocessor controlled, with a } \\
\text { photomultiplexer tube and one reaction } \\
\text { chamber which are time-multiplexed for } \\
\text { NO and } \mathrm{NO}_{\mathrm{x}} \text { measurements }\end{array}$ & & & \\
\hline $\begin{array}{l}\text { Sulfur Dioxide } \\
\text { Ambient Air } \\
\text { Analyzer }\end{array}$ & $\begin{array}{l}\text { Low level pulsed fluorescence } \mathrm{SO}_{2} \\
\text { analyzer with a detection limit of } 0.1 \\
\text { ppb. Analyzer must require no } \\
\text { consumable gases or wet chemistry; } \\
\text { must meet or exceed EPA Reference or } \\
\text { Equivalent Methods requirements }\end{array}$ & 2 & $\$ 10,300$ & $\$ 20,600$ \\
\hline $\begin{array}{l}\text { Multi Gas Calibration } \\
\text { System }\end{array}$ & $\begin{array}{l}\text { Supplies known levels of } \\
\mathrm{NO} / \mathrm{NO}_{2} / \mathrm{NO}_{\mathrm{x}} / \mathrm{SO}_{2} \text { to perform zero, } \\
\text { precision and level } 1 \text { span checks, } \\
\text { audits, and multipoint calibration of } \\
\text { instrument response to these gases. } \\
\text { This system must be compatible with } \\
\text { the } \mathrm{NO} / \mathrm{NO}_{2} / \mathrm{NO}_{x} \text { and } \mathrm{SO}_{2} \text { monitoring } \\
\text { systems. }\end{array}$ & 1 & $\$ 9,000$ & $\$ 9,000$ \\
\hline $\begin{array}{l}\text { Laboratory } \\
\text { Desiccator }\end{array}$ & $\begin{array}{l}\text { Stainless steel and glass with shelves } \\
\text { sized large enough to accommodate at } \\
\text { least three } 8^{\prime \prime} \times 10^{\prime \prime} \text { filters. Must also } \\
\text { include desiccant material or indicating } \\
\text { desiccant sealed in an over-safe pouch }\end{array}$ & 1 & $\$ 900$ & $\$ 900$ \\
\hline Generator & $\begin{array}{l}\text { Portable propane powered electric } \\
\text { generator with weather proof enclosure. } \\
\text { The capacity must be sufficient to meet } \\
\text { all power needs of the monitoring } \\
\text { equipment. }\end{array}$ & 2 & $\$ 16,000$ & $\$ 32,000$ \\
\hline $\begin{array}{l}\text { Solar Powered } \\
\text { Sampling System }\end{array}$ & $\begin{array}{l}\text { House in metal case. Ambient air } \\
\text { hazardous material detection with EPA } \\
\text { PM-10 standards. Self-powered with } \\
\text { solar panels. Unit is Portable. }\end{array}$ & 2 & $\$ 4,000$ & $\$ 8,000$ \\
\hline Calibration Gases & $\begin{array}{l}\text { Gases include: } 1 \text { ) compressed gas } \\
\text { cylinder containing } 50 \text { ppm nitrate oxide } \\
\text { in nitrogen, approximately } 27 \text { cubic feet; } \\
\text { must contain less than } 1 \mathrm{ppm} \mathrm{NO}_{2} .2 \text { ) } \\
\text { compressed gas cylinder containing } 5 \\
\text { ppm nitric oxide in nitrogen } \\
\text { approximately } 27 \text { cubic feet; must } \\
\text { contain less than } 0.5 \mathrm{ppm} \text { NO2. } 3 \text { ) } \\
\text { compressed gas cylinder containing } 5 \\
\text { ppm sulfur dioxide in air (substitute } 10 \\
\text { ppm } \mathrm{SO}_{2} \text { if } 5 \text { ppm in not available), } \\
\text { approximately } 20 \text { cubic feet }\end{array}$ & 3 & $\$ 100$ & $\$ 300$ \\
\hline $\begin{array}{l}\text { Compressed Gas } \\
\text { Regulators }\end{array}$ & $\begin{array}{l}\text { Ultra high purity low dead volume } \\
\text { compressed gas regulators with a } \\
\text { delivery pressure range of } 2 \text { to } 100 \\
\text { psig. Must have a minimum internal } \\
\text { volume design, fabricated out of } \\
\text { stainless steel. }\end{array}$ & 2 & $\$ 300$ & $\$ 600$ \\
\hline Trailers & $\begin{array}{l}\text { Enclosed utility trailers to serve as } \\
\text { weather housing for instruments, } 18 \text { to } \\
20 \text { feet long. Trailer contains electrical }\end{array}$ & 1 & $\$ 25,000$ & $\$ 25,000$ \\
\hline
\end{tabular}




\begin{tabular}{|c|l|l|c|c|}
\hline EQUIPMENT & \multicolumn{1}{|c|}{ DESCRIPTION } & \multicolumn{1}{c|}{$\begin{array}{c}\text { UNITS } \\
\text { REQUIRED }\end{array}$} & $\begin{array}{c}\text { UNIT } \\
\text { COST }\end{array}$ & $\begin{array}{c}\text { TOTAL } \\
\text { COST }\end{array}$ \\
\hline & $\begin{array}{l}\text { heating capable of maintaining a } \\
\text { minimum temperature of } 55 \text { degree } F, \\
\text { under extreme weather conditions. } \\
\text { Trailer contains heat pump air } \\
\text { conditioning capable of maintaining } \\
\text { temperature below } 80 \text { degree } \mathrm{F} .\end{array}$ & & & \\
\hline
\end{tabular}

The approximate cost for the monitoring equipment listed in Table 1 is $\$ 140,000$. 